\title{
Validation of A High Performance Liquid Chromatography Method to Quantify Thymol in Nanocapsules of Bioactive Essential Oil from Lippia Sidoides
}

Abstract

The essential oil of $L$. sidoides is a derivative of a natural product with antimicrobial antioxidade and has great potential for medical use. The objective of this study was to validate a method for HPLC-DAD for quantification of thymol, an important compound of essential oil in nanocapsules containing the essential oil of $L$. sidoides. The method was linear in the range of $4-180 \mu \mathrm{g} \mathrm{mL}^{-1}$, with a good correlation coefficient $(\mathrm{r}=0.9994)$. Precision and accuracy analysis showed low relative standard deviation $(<2.27 \%)$ and a good recovery percentage $(97.2-98.2 \%)$. The procedure proved to be specific, linear, precise, exact and robust so that the method can be applied in quantification of thymol in suspensions of nanocapsules containing the essential oil of L. sidoides.

Keywords: Validation; Lippia sidoides; Thymol; Nanocapsules; Essential oil; HPLCDAD

Abbreviations: ANVISA: Agência Nacional De Vigilância Sanitária (National Health Surveillance Agency Brazil); ICH: Conference of Harmonization; GC-MS: Gas ChromatographyMass Spectrometry; LC-MS: Liquid Chromatography-Mass Spectrometry; LOQ: Quantification; LOD Limits of Detection; HPLC-UV: High Performance Liquid Chromatography And Ultravioleta Detector; HPLC-DAD: High Performance Liquid Chromatography and Diode Array Detector; NCB: Blank Nanocapsules; NCLS: Nanocapsules Containing Essential Oil of L. Sidoides; ODS: Octadecylsilyl Groups; OELS: Essential Oil of Lippia Sidoides; PLGA: Poly D, L-Lactide-Co-Glycolyde; PTFE: Polytetrafluoroethylene; R.S.D: Relative Standard Deviation

\section{Introduction}

Lippia sidoides Cham. (Verbenaceae), popularly known as rosemary pepper, is an aromatic shrub native to the Brazilian Northeast [1]. The essential oil extracted from its leaves has a high concentration of thymol, a component of potent antimicrobial activity. Studies have reported that the essential oil of L. sidoides has several biological properties including antimicrobial [2,3], antifungal $[4,5]$, antioxidant $[6,7]$, and topical anti-inflammatory $[7,8]$. However, some studies report irritant action of the mucosa when the essential oil is applied directly to the skin [9]. Thus the essential oil of $L$. sidoides was encapsulated in polymeric nanocapsules in order to decrease the toxic effects and maintain or increase its therapeutic efficiency, because this is one of the purposes of nanoencapsulation [10]. High-performance liquid chromatography is one of the quantification techniques commonly used for drug analysis in the pharmaceutical industry, and has been a widely used methodology in the analysis of conveyed drugs in nanocarriers [11-13] For essential oils, gas chromatography analysis techniques are generally employed, however, thymol,

\author{
Research Article \\ Volume 10 Issue 2 - 2017 \\ Bianca Oliveira Louchard ${ }^{1}$, Larissa Coelho \\ Costa $^{1}$, Angelo Roncalli Alves e Silva ${ }^{2}$ and \\ Luzia Kalyne Almeida Moreira Leal ${ }^{1 *}$ \\ ${ }^{1}$ Department of Pharmacy, Federal University of Ceará - UFC, \\ Brazil \\ ${ }^{2}$ Department of Pharmacy, University of Fortaleza- UNIFOR, \\ Brazil \\ *Corresponding author: Kalyne Almeida Moreira Leal, \\ CEFAC, Centro de Estudos Farmaceuticos e Cosméticos, \\ Departamento de farmácia, Universidade Federal do Ceará \\ - UFC, Rua Capital Francisco Pedro, 1210, Rodolfo Teofilo, \\ Fortaleza-CE, Brazil, Tel: 5585 3366-8249; Fax: 5585 3366- \\ 8292; Email: kalyneleal@gmail.com
}

Received: July 26, 2017 | Published: December 27, 2017

which is the major component and the pharmacological marker in L. sidoides essential oil, has an absorption spectra in the ultraviolet region. This fact allows the quantification of thymol in essential oils, plant extracts and nanocarriers by HPLC-UV and HPLC-DAD, as has been reported in several studies. ${ }^{14-17}$ Therefore, the aim of this study was to validate an analytical methodology by HPLC-DAD, for quantification of thymol in essential oil and nanocapsules containing essential oil of $L$. sidoides.

\section{Materials and Methods}

\section{Reagents, solvents and materials}

Thymol (99.5 \% purity), PLGA (Poly D, L-lactide-coGlycolyde 50:50) and poloxamer 188 (Poly(ethylene glycol)block-poly(propylene glycol)-block-poly(ethylene glycol) were purchased from Sigma Aldrich (São Paulo, USA), acetonitrile grade HPLC and acetone grade P.A. were purchased from Tedia (New Janeiro BR), water purified through milli-q filter system (Milipore, Brazil), phosphatidylcholine (Lipoid S-100) were purchased from Lipoid (Newark, USA), essential oil of Lippia sidoides (OELS) was purchased from Padetec (Fortaleza, BR), Millex-LCR filter with

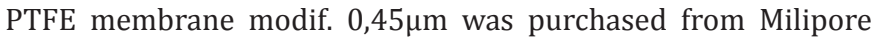
(São Paulo, BR).

\section{Instrumentation}

The chromatographic analyzes were performed on a liquid chromatography (Waters Alliance 2695, USA) with diode array 
detector (Waters Alliance 2996, USA). Analytical separation was achieved on a reversed phase $\mathrm{C}_{18}$ column ODS Hypersil (Thermo $250 \mathrm{~mm} \times 4.6 \mathrm{~mm}, 5 \mu \mathrm{m}$ particle size), coupled to a $\mathrm{C}_{18}$ security guard pre-column (Thermo $10 \times 4 \mathrm{~mm}$ ). A rotary evaporator (Heidolph G3, Germany) and magnetic stirring (Quimis 601.2, Brasil) were used.

\section{Preparation of nanocapsules}

Nanocapsules containing essential oil of L. sidoides (NCLS - 7,5mg $\mathrm{mL}^{-1}$ of OELS) ( $\mathrm{n}=3$ batches) and blank nanocapsules (NCB) were obtained by nanoprecipitation of preformed polymer [18] PLGA (36mg), phosphatidylcholine (90mg) and (0.01g) were dissolved in acetone $(15 \mathrm{~mL})$ at $40{ }^{\circ} \mathbf{C} \pm 2$. This organic phase was injected into an aqueous phase at $40^{\circ} \mathbf{C} \pm 2$, containing poloxamer $188(180 \mathrm{mg})$ and ultrapurified water $(30 \mathrm{~mL})$ under magnetic stirring. After $10 \mathrm{~min}$, acetone was eliminated and the suspension concentrated to $10 \mathrm{~mL}$ under reduced pressure (rotary evaporator). Blank nanocapsules were prepared in the same manner, but the OELS was not added to the organic phase.

\section{Chromatographic parameters}

The chromatographic conditions were: column temperature $40^{\circ} \mathrm{C}$, mobile phase acetonitrile: water $(78: 22)$, isocratic elution mode, flow $0.8 \mathrm{ml} \mathrm{min} \mathrm{min}^{-1}$, detection wavelength $278 \mathrm{~nm}$, sample injected volume $20 \mu \mathrm{L}$, and run time $8 \mathrm{~min}$. Before delivering the mobile phase into the system, it was degassed for $30 \mathrm{~min}$ by sonication and filtered through $0.45 \mu \mathrm{m}$ filter using vacuum. These experimental conditions were established on a method previously developed by our research group for the quantification of thymol in leaf extracts of L. sidoides [14].

\section{Preparation of standard solutions}

The amount of $10 \mathrm{mg}$ of thymol reference standard was transferred to a $10 \mathrm{~mL}$ volumetric flask and the volume was completed with the mobile phase. From this, thymol stock solution (1 $\left.\mathrm{mg} \mathrm{mL}^{-1}\right)$ was prepared by 8 dilutions for construction of the calibration curve $\left(8 \mu \mathrm{g} \mathrm{mL}^{-1}, 10 \mu \mathrm{g} \mathrm{m}^{-1}, 20 \mu \mathrm{g} \mathrm{mL}^{-1}, 30 \mu \mathrm{g}\right.$ $\left.\mathrm{mL}^{-1}, 50 \mu \mathrm{g} \mathrm{mL}{ }^{-1}, 100 \mu \mathrm{gL}^{-1}, 150 \mu \mathrm{gL}^{-1}, 180 \mu \mathrm{g} \mathrm{m}^{-1}\right)$.

\section{Preparation of samples solutions}

OELS samples were prepared by weighing approximately $20 \mathrm{mg}$ OELS directly into a $10 \mathrm{ml}$ volumetric flask using an analytical balance (Toledo, Brazil), the volume was completed with the mobile phase. From this solution $\left(2 \mathrm{mg} \mathrm{ml}^{-1}\right.$ OELS), dilutions were prepared $16-24 \mu \mathrm{g} \mathrm{ml}^{-1}$ OELS as required for the test. The samples NCLS or NCB were prepared by adding $80-120 \mu \mathrm{L}$ of the sample in a volumetric flask of $10 \mathrm{ml}$ and completing the volume with mobile phase. The standard and sample solutions were always prepared on the day of analysis, filtered through a $0.45 \mu \mathrm{m}$ membrane (Millipore, USA) and transferred to a vial for injection equipment.

\section{Method validation}

The method was validated according to the International Conference of Harmonization (ICH) and the ANVISA Resolution RE 899/2003 guideline [19], considering the following parameters: specificity, linearity, precision, repeatability, accuracy, recovery, limit of quantification, limit of detection and robustness.

a. Specificity: To assess specificity, comparative analyses of the tymol, OELS, NCLS and NCB were performed in order to evaluate if any formulation components interfered with thymol quantification.

b. Linearit: The linearity of the method was evaluated through the detector response to different concentrations of thymol, OELS and the NCLS. Linearity determination was conducted by quantifying three different thymol standard curves (ranging from 4 - $180 \mu \mathrm{g} \mathrm{mL} \mathrm{L}^{-1}$ ) prepared daily for two consecutive days. The linearity of OELS and NCLS were determined at 5 concentration levels measured in triplicate corresponding to the range of $80,90,100,110$ and $120 \%$ of the theoretical concentration of the test for OELS and the NCLS. Thus, OELS dilutions were prepared containing $16 \mu \mathrm{g}$ $\mathrm{mL}^{-1}, 18 \mu \mathrm{g} \mathrm{mL}^{-1}, 20 \mu \mathrm{gL}^{-1}, 22 \mu \mathrm{gL}^{-1}$ and $24 \mu \mathrm{gL}^{-1}$, and NCLS dilutions were prepared containing $8 \mu \mathrm{L} \mathrm{mL}^{-1}, 9 \mu \mathrm{L} \mathrm{mL}$ ${ }^{1}, 10 \mu \mathrm{L} \mathrm{m}^{-1}, 11 \mu \mathrm{L} \mathrm{mL}^{-1}$ and $12 \mu \mathrm{L} \mathrm{mL}^{-1}$. It is noteworthy that each $1 \mu \mathrm{g}$ OELS corresponds on average to $0.6 \mu \mathrm{g}$ of thymol, and that every $1 \mu \mathrm{L}$ of NCLS corresponds to approximately $3.2 \mu \mathrm{g}$ of thymol, so all concentrations of both NCLS and OELS are within the range of the thymol concentration calibration curve. The results were processed in Microsoft Excel. The curve equation was obtained by plotting substance (Thymol, OELS or NCLS) peak mean areas against the respective nominal concentration on a Cartesian axis. By using linear regression analysis (least square regression method) the slopes, intercepts and determination coefficients were calculated. The validity of the assay was verified by means of the one-way ANOVA ( $\alpha=0.05)$.

c. The limit of detection and quantification: The limits of detection (LOD) and quantification (LOQ) were determined based on the standard deviation of the data and the intercept average slope obtained from the three calibration curves of thymol standard [20].

d. Precision: The precision assay was investigated with respect to repeatability Intra-day precision (repeatability) and Inter-day precision (intermediate precision). The results were expressed as a percentage of the nominal content of OELS where $100 \%$ corresponds to the content of thymol concentration of $600 \mathrm{mg} \mathrm{ml}^{-1}$, and the NCLS $100 \%$ corresponds to the content of thymol concentration of $3.2 \mathrm{mg}$ $\mathrm{ml}^{-1}$. Precision was given as the relative standard deviation (RSD \%).

e. Repeatability: The repeatability was evaluated by performing six determinations of OELS sample, and six determinations of NCLS samples, at concentrations of $20 \mu \mathrm{g} \mathrm{ml}^{-1}$ and $10 \mu \mathrm{ml}^{-1}$ respectively, corresponding to $100 \%$ of the theoretical test concentration. These samples were prepared by the same analyst on the same day using the same instrumentation and injected into the equipment.

f. Intermediate precision: Intermediate precision was verified by evaluating three concentrations of OELS, and three concentrations of NCLS, corresponding to 80, 100 and 
$120 \%$ of the theoretical concentration, which is equivalent to dilution of $16 \mu \mathrm{g} \mathrm{mL}^{-1}, 20 \mu \mathrm{g} \mathrm{mL}^{-1}$ and $24 \mu \mathrm{g} \mathrm{mL}^{-1}$ for OELS and 8 $\mu \mathrm{L} \mathrm{ml}^{-1}, 10 \mu \mathrm{L} \mathrm{ml}^{-1}$ and $12 \mu \mathrm{L} \mathrm{mL}^{-1}$ for NCLS. Each concentration was prepared in triplicate. These solutions were prepared on two different days by two different analysts. The equality of variances was evaluated by $\mathrm{F}$ test and the results were expressed by the relative standard deviation (RSD).

g. Accuracy: The accuracy was determined by recovery test by adding a known amount of thymol in three concentrations (low - $10 \mu \mathrm{gLL}^{-1}$, medium - $50 \mu \mathrm{g} \mathrm{mL}^{-1}$, and high - $100 \mu \mathrm{gL}^{-1}$ ), following the linear range of the method and comparing the results obtained with the same concentrations of standard reference. Thus, three standard concentrations were prepared $\left(10 \mu \mathrm{g} \mathrm{mL}^{-1}, 50 \mu \mathrm{g} \mathrm{mL}^{-1}\right.$, and $\left.100 \mu \mathrm{g} \mathrm{m}^{-1}\right)$ of thymol, three concentrations of OELS with added standard thymol (50\% OELS + $50 \%$ thymol), and three concentrations of NCB formulation with added thymol, the corresponding concentrations were of low, medium and high doses of the test concentration. The accuracy is determined by the ratio of the average concentration of the added standard solution to the corresponding concentration of the standard solution.

\section{Robustness}

The robustness of the method was assessed by varying the parameters of the column temperature, flow rate of mobile phase and column manufacturer, as described in Table 1. Samples corresponding to $100 \%$ of the theoretical test concentration corresponding to $20 \mu \mathrm{g} \mathrm{ml}^{-1}$ of OELS were evaluated. The results were expressed as percentage of $100 \%$ nominal content where content corresponded to $600 \mathrm{mg}$ of thymol in each $\mathrm{mL}$ of OELS Statistical analysis was by the ANOVA analysis of variance followed by Tukey's test, the results were considered significant when $\mathrm{p}<0.05$.

Table 1: Parameters evaluated in verifying the robustness.

\begin{tabular}{|c|c|c|c|c|}
\hline \multirow{2}{*}{ Standard Method } & \multicolumn{3}{c|}{ Challenging Conditions } \\
\cline { 2 - 5 } & $\mathbf{1}$ & $\mathbf{2}$ & $\mathbf{3}$ \\
\hline Temperature & $40{ }^{\circ} \mathbf{C}$ & $30^{\circ} \mathbf{C}$ & $40^{\circ} \mathrm{C}$ & $40{ }^{\circ} \mathbf{C}$ \\
\hline Column supplier & Termo & Thermo & Fenomenex & Thermo \\
\hline Flow (ml min-1) & 0.8 & 0.8 & 0.8 & 1 \\
\hline
\end{tabular}

\section{Results and Discussion}

The selectivity or specificity is considered the first step of validating analytical methods, it is through this study that it can be inferred that the components of the matrix or excipients do not interfere with the quantification of the drug [21]. The specificity of the methodology related to testing showed that the method was capable of identifying the component of thymol retention time at $4.95 \mathrm{~min}$ for both OELS and NCLS (Figure 1). The chromatographic analysis showed that the NCB excipients that make up the matrix of the nanocapsules thymol did not interfere with the analysis by this method since there was no appearance of other peaks in the chromatogram. Therefore, we can conclude that the proposed method is specific for quantification of thymol in NCLS. The analysis of the linearity parameter provides information about the ability of the method to provide results that are proportional to the concentration of analyte in the sample [22].

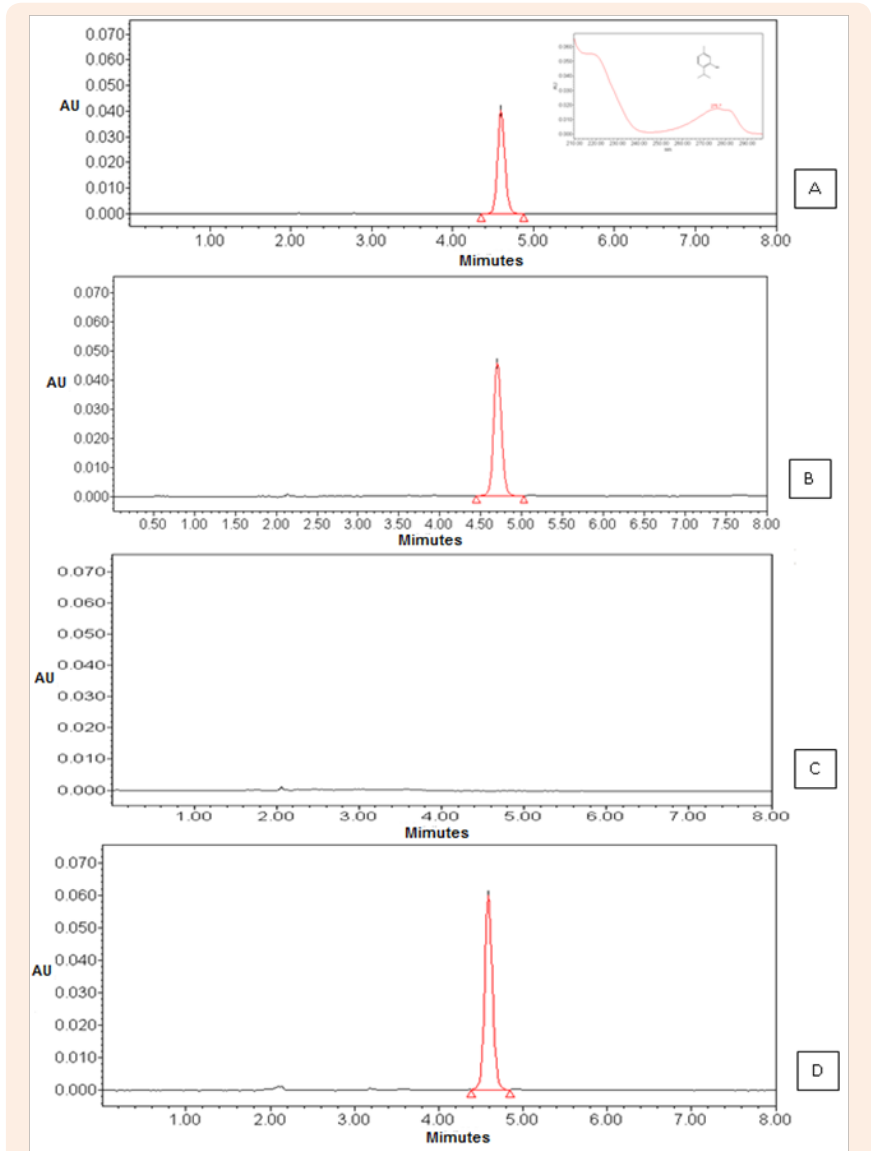

Figure 1: Chromatograms corresponding to: $(A)$ the peak thymol and UV spectrum (B) the peak thymol in OELS viewed by HPLC-DAD observed at 4.9 minutes (C) blank nanocapsules and (D) the peak thymol in nanocapsules.

The linearity was studied by analysis of variance, calculating the linear regression by the method of least squares by using a curve consisting of 5 concentrations in triplicate, the OELS and NCLS within the concentration range set for thymol $(4-180 \mu \mathrm{g}$ $\mathrm{mL}^{-1}$ ). The analytical curves in triplicate with seven standard concentrations of thymol showed a correlation coefficient (r) of 0.9994, the equation of the straight line obtained was of the type $y=a \cdot x+b$ where $y$ is the peak area which is a linear function of the concentration of the substance " $x$ ". Figure 2 graphically demonstrates the analytical curve of thymol and the equation of the corresponding $\mathrm{y}=24592 \mathrm{x}-19984$.

The curves of the five concentrations of oils and NCLS evaluated showed a correlation coefficient of (r) 0.9991 and 0.9979 respectively. An important factor in evaluating the method of linearity is the analysis of waste graph. Through this analysis it is possible to detect problems in curve fitting, such as linearity deviation, presence of atypical sample heteroscedasticity, and dependence between the errors. So a well-adjusted curve must have errors with uniform distribution, zero mean and constant 
variance (homoscedasticity), as well as the absence of atypical strains [20]. As can be seen in Figure 3 relating to waste curves obtained with the OELS and the NCLS, they proved to be normally and independently distributed around zero, demonstrating the absence of waste there between.

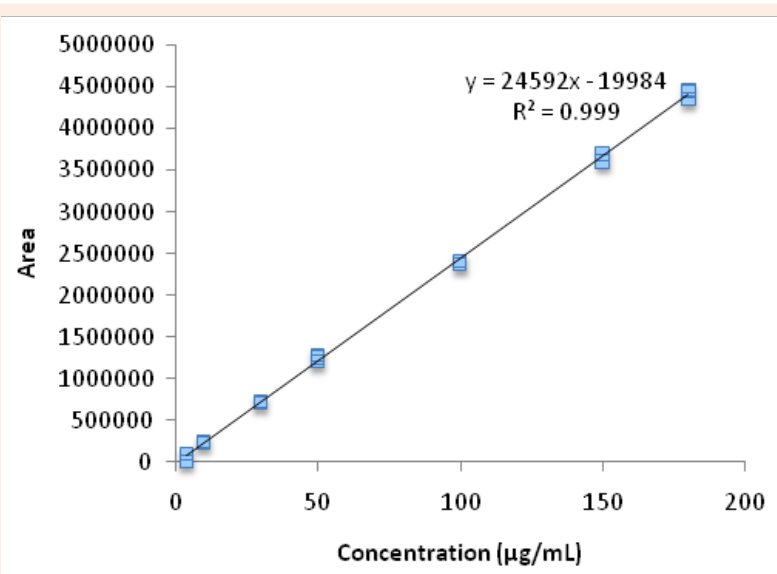

Figure 2: Graphical representation of the calibration curve obtained by HPLC-DAD, referring to seven concentrations of thymol $(4-180 \mu \mathrm{g}$ $\mathrm{ml}^{-1}$ ) evaluated in the study of method linearity.

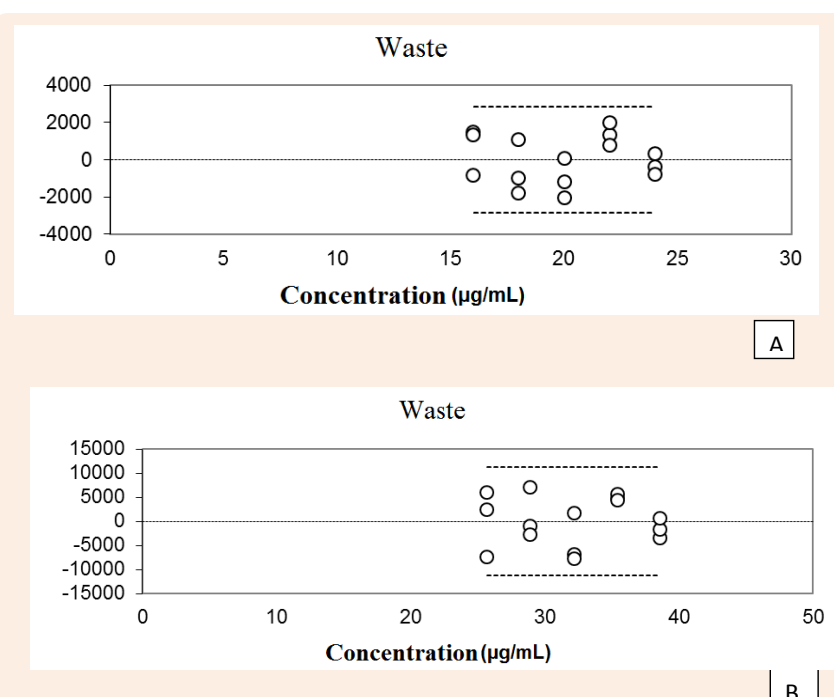

Figure 3: The graphical representation of waste relating to the five concentrations of OELS (A) and NCLS (B).

According to Ribeiro et al. [20] waste represents the portion of data variability that is not explained by the adjustment, and can be interpreted as an estimate of the model error. In this way, the graphical representation of waste must be normally and independently distributed around zero, and must have zero mean and constant variance. In the present study, the waste graphic pattern regarding thymol, OELS and the NCLS showed this behavior. The analysis of variance (ANOVA) conducted for the calibration curve of thymol $(\mathrm{P}=0.57)$, OELS $(\mathrm{P}=0.39)$ and NCLS $(P=0.20)$ demonstrated that the present method does not present a significant linearity deviation. Thus we can infer that the developed method has linear response to the detector of the thymol in the range of $4-180 \mu \mathrm{gL}^{-1}$. Statistical analysis of the data relating to the linearity of the method allowed the calculation of the limit of detection (LOD) and the limit of quantification (LOQ) through a reliable calibration curve range. The limit of detection for thymol assay was $0.4 \mu \mathrm{g} \mathrm{ml}^{-1}$ and the quantitation limit was $1.02 \mu \mathrm{g} \mathrm{mL}^{-1}$. The analytical method should ensure a reliable analysis of the drug to be quantified, so it must be accurate, and present minimum dispersion between the results of the readings at the same concentration and at the same time be accurate, which means that there must be agreement between individual results in the same test or self-test, compared to a reference value accepted as true [21]. The accuracy test evaluated the concordance of results at repeatability levels (within-run precision) and intermediate precision (inter-run precision). The OELS and NCLS showed RSD values of 1.05 and 2.22 respectively for repeatability at $100 \%$ of theoretical test concentration (Tables $2 \& 3$ ). In the evaluation of intermediate precision, the RSD values for OELS ranged from 0.62 to 3.06 , and for the NCLS the values ranged from 0.34 to 3.71 (Tables $4 \& 5$ ). The F test (ANOVA) applied to evaluate the homogeneity of variance in the intermediate accuracy test showed no significant differences between the analyses carried out by different analysts or on different days ( $p>0.05$ ) for both OELS and NCLS, as can be seen in Tables $6 \& 7$. Therefore from the results we can infer that the method is accurate.

Table 2: Thymol quantification results in OELS performed in a single day regarding the repeatability test (within-run precision).

\begin{tabular}{|c|c|c|c|}
\hline Concentration & Content \% & Average & RSD \\
\hline & 101.1 & \multirow{7}{*}{100.5} & \multirow{7}{*}{1.05} \\
\hline & 99.7 & & \\
\hline & 101.6 & & \\
\hline & 101.1 & & \\
\hline & 98.8 & & \\
\hline & 100.8 & & \\
\hline & $100 \%$ & & \\
\hline
\end{tabular}

Results are expressed as nominal content of thymol in OELS, referring to the mean \pm standard deviation of three replicas, where $100 \%$ of content is equivalent to $600 \mathrm{mg}$ of thymol per $1 \mathrm{~mL}$ of OELS.

Table 3: Thymol quantification results in NCLS performed in a single day regarding the repeatability test (within-run precision)

\begin{tabular}{|c|c|c|c|}
\hline Concentration & Content \% & Average & RSD\% \\
\hline \multirow{2}{*}{$100 \%$} & 99.4 & \\
\cline { 2 - 2 } & 95.6 & \\
\cline { 2 - 2 } & 99.4 & \multirow{2}{*}{9} & \\
\cline { 2 - 2 } & 102.4 & \\
\cline { 2 - 2 } & 100.5 & \\
\cline { 2 - 2 } & 99.6 & \\
\hline
\end{tabular}

Results are expressed as nominal content of thymol in NCLS concerning the mean \pm standard deviation of three replicates, where $100 \%$ of theory is equivalent on average to $3.2 \mathrm{mg}$ thymol per $1 \mathrm{ml}$ NCLS. 
Table 4: Quantification of thymol in OELS.

\begin{tabular}{|c|c|c|c|c|c|c|c|}
\hline \multirow{2}{*}{ Day } & Analyst & \multicolumn{6}{|c|}{ Concentration } \\
\hline \multirow{2}{*}{} & & \multicolumn{2}{|c|}{$\mathbf{8 0} \%$} & \multicolumn{2}{|c|}{$\mathbf{1 0 0 \%}$} & \multicolumn{2}{c|}{$\mathbf{1 2 0 \%}$} \\
\cline { 2 - 8 } & & Content (\%) & RSD \% & Content (\%) & RSD \% & Content (\%) & RSD \% \\
\hline 1 & I & 100.4 & 0.62 & 99.8 & 3.06 & 100.6 & 1.27 \\
\hline & II & 98.4 & 0.34 & 99.7 & 1.8 & 100.8 & 1.98 \\
\hline 2 & I & 100.9 & 1.06 & 100 & 0.34 & 99.4 & 1.34 \\
\hline
\end{tabular}

Results are expressed as nominal content of thymol in OELS, referring to the mean \pm standard deviation of three replicas, where $100 \%$ of content is equivalent to $600 \mathrm{mg}$ of thymol per $1 \mathrm{~mL}$ of OELS. Results for the intermediate precision test (inter run precision).

Table 5: Quantification of active thymol in NCCLS. Results for the intermediate precision test (inter run precision).

\begin{tabular}{|c|c|c|c|c|c|c|c|}
\hline \multirow{2}{*}{ Day } & Analyst & \multicolumn{6}{|c|}{ Concentration } \\
\hline \multirow{2}{*}{} & & \multicolumn{2}{|c|}{$\mathbf{8 0 \%}$} & \multicolumn{2}{c|}{$\mathbf{1 0 0 \%}$} & \multicolumn{2}{c|}{$\mathbf{1 2 0 \%}$} \\
\cline { 2 - 7 } & & Content (\%) & RSD \% & Content (\%) & RSD \% & Content (\%) & RSD \% \\
\hline 1 & I & 103.4 & 0.62 & 99.8 & 3.06 & 100.6 & 1.27 \\
\hline & II & 98.4 & 0.34 & 99.7 & 1.8 & 100.8 & 1.98 \\
\hline 2 & I & 100.9 & 1.06 & 100 & 0.34 & 99.4 & 1.34 \\
\hline
\end{tabular}

\begin{tabular}{|c|c|c|c|c|c|c|c|}
\hline \multirow{2}{*}{ Dia } & \multirow{2}{*}{ Analyst } & \multicolumn{3}{|c|}{ Concentration } \\
\hline & & \multicolumn{2}{|c|}{$\mathbf{8 0 \%}$} & \multicolumn{2}{c|}{$\mathbf{1 0 0 \%}$} & \multicolumn{2}{c|}{$\mathbf{1 2 0 \%}$} \\
\cline { 2 - 7 } & & Content (\%) & RSD \% & Content (\%) & RSD \% & Content (\%) & RSD \% \\
\hline 1 & I & 103.4 & 2.18 & 98.9 & 1.34 & 99.4 & 0.34 \\
\hline & II & 102.8 & 1.68 & 95.5 & 3.71 & 102.4 & 1.42 \\
\hline 2 & I & 103.2 & 1.62 & 99.5 & 2.1 & 101.9 & 2.27 \\
\hline
\end{tabular}

Results are expressed as nominal content of thymol in NCLS concerning the mean \pm standard deviation of three replicates, where $100 \%$ of theory is equivalent on average to $3.2 \mathrm{mg}$ thymol per $1 \mathrm{ml}$ NCLS.

Table 6: Statistical evaluation of results for the intermediate precision test for OELS.

\begin{tabular}{|c|c|c|c|c|c|c|c|}
\hline \multirow[t]{3}{*}{ Experimental Condition } & \multicolumn{7}{|c|}{ Concentration } \\
\hline & \multicolumn{2}{|c|}{$80 \%$} & \multicolumn{2}{|c|}{$100 \%$} & \multicolumn{2}{|c|}{$120 \%$} & \multirow{2}{*}{$F_{\text {crit }}$} \\
\hline & $F$ & $\mathbf{P}$ & $\boldsymbol{F}$ & $\mathbf{P}$ & $\boldsymbol{F}$ & $\mathbf{P}$ & \\
\hline Day 1 analyst I versus day 1 analyst II & 9.512 & 0.091 & 0.003 & 0.961 & 0.027 & 0.885 & \multirow{2}{*}{18.513} \\
\hline Day 1 analyst I versus day 2 analyst I & 0.108 & 0.773 & 0.076 & 0.808 & 0.977 & 0.427 & \\
\hline
\end{tabular}

Table 7: Statistical evaluation of results for the intermediate precision test for NCLS.

\begin{tabular}{|c|c|c|c|c|c|c|c|}
\hline \multirow[t]{3}{*}{ Experimental Condition } & \multicolumn{7}{|c|}{ Concentration } \\
\hline & \multicolumn{2}{|c|}{$80 \%$} & \multicolumn{2}{|c|}{$100 \%$} & \multicolumn{2}{|c|}{$120 \%$} & \multirow{2}{*}{$F_{\text {crit }}$} \\
\hline & $F$ & $\mathbf{P}$ & $F$ & $\mathbf{P}$ & $F$ & $\mathbf{P}$ & \\
\hline Day 1 analyst I versus day 1 analyst II & 1.31 & 0.37 & 0.72 & 0.48 & 4.25 & 0.17 & \multirow{2}{*}{18.51} \\
\hline Day 1 analyst I versus day 2 analyst I & 0.66 & 0.49 & 6.36 & 0.12 & 1.36 & 0.36 & \\
\hline
\end{tabular}


Table 8. Results of the recovery method for thymol assay in OELS and NCLS.

\begin{tabular}{|c|c|c|c|c|c|c|}
\hline Concentration & \multicolumn{3}{|c|}{ OELS } & \multicolumn{2}{c|}{ NCLS } \\
\hline & Recovery (\%)* & Average (\%) & RSD\% & Recovery (\%)* & Average (\%) & RSD\% \\
\hline $10 \mu \mathrm{g} \mathrm{mL}-1$ & $96.1 \pm 0,05$ & & & $99.9 \pm 3.81$ & & \\
\hline $50 \mu \mathrm{g} \mathrm{mL}-1$ & $97.6 \pm 1,23$ & 97.24 & 1.04 & $98.6 \pm 1.60$ & 98.2 & 1.98 \\
\hline $100 \mu \mathrm{g} \mathrm{mL}-1$ & $98.0 \pm 2.13$ & & & $96.1 \pm 2.99$ & & \\
\hline
\end{tabular}

*Results of the mean \pm standard deviation of 3 determinations

Table 9: Influence of temperature, column provider and the mobile phase flow, the robustness of the measurement method of thymol.

\begin{tabular}{|c|c|c|c|}
\hline Condition standard method & Temperature & Column & Flow \\
\hline & $30{ }^{\circ} \mathrm{C}$ & Fenomenex & $1,0 \mathrm{~mL} \mathrm{~min}-1$ \\
\hline \multicolumn{4}{|c|}{ Teor $(\%)$} \\
\hline $101.8 \pm 0.96$ & $99.3 \pm 2,87$ & $98.3 \pm 2.14$ & $101.8 \pm 4.47$ \\
\hline
\end{tabular}

The accuracy test is to prove the efficacy of the method for quantifying the analyte in the sample [22]. According to Brito [23], the accuracy is expressed as a percentage of systematic error inherent in the process. This systematic error may occur due to low recovery of the analyte in the extraction process, inaccurate volumetric measurements or interfering substances in the sample. The accuracy of analysis results conducted at three concentration levels for OELS and the NCLS are expressed in Table 8. As can be seen the method had a recovery of around $97.24 \%$ with RSD of 1.04 for the quantification of thymol in OELS and a recovery of $98.2 \%$ with RSD of 1.98 for NCLS.

The robustness of the method was assessed by varying the temperature parameters of the column, the mobile phase flow and the column manufacturer. As can be seen in Table 9, none of the parameters significantly impact the dosing of the active thymol $(\mathrm{P}=0.3929)$. The robustness test identifies the method of factors that have a significant effect on the results and anticipate problems that may arise during the application of the method on different instruments, using different reagents, chromatographic columns, and in different environments [24]. Therefore, from the results presented we can infer that the developed method can be considered robust for the tested parameters.

\section{Conclusion}

The results of our study demonstrate the suitability of the method for quantification of thymol using HPLC-DAD. The method proved to be simple, rapid, specific, linear, accurate and robust for sensitive quantification of the active thymol in essential oil as well as in nanocapsules containing the essential oil of $L$. sidoides. The analytical procedure has a total analysis time of eight minutes which allows for the analysis of a large number of samples in a short time. Therefore, it is suitable for routine analysis of both raw material of OELS and the formulation of nanocapsules containing OELS. The simplicity of the method allows the for application in laboratories that do not have access to sophisticated analytical instruments such as LC-MS or GC-MS equipment, which need a more complicated, more costly and time consuming analysis.

\section{Acknowledgements}

This work was supported by the CAPES and CNPq

\section{Conflict of Interest}

The authors declare that there is no conflict of interest

\section{References}

1. Matos FJ (2007) Plantas medicinais - Guia de seleção e emprego de plantas medicinais usadas em fitoterapia no nordeste do Brasil. $\left(2^{\text {nd }}\right.$ edn), UFC, Fortaleza, Brazil.

2. Veras HN, Rodrigues FF, Botelho MA, Menezes IR, Coutinho HD, et al (2013) Enhancement of aminoglycosides and $\beta$-lactams antibiotic activity by essential oil of Lippia sidoides Cham. and the Thymol. Arabian J Chem 10(2): S2790-2795.

3. Costa JPR, de Almeida AC, Martins ER, Rodrigues MN, dos Santos CA, et al. (2011) Atividade antimicrobiana do óleo essencial de alecrim-pimenta e do extrato bruto seco do barbatimão diante de bactérias isoladas do leite. Biotemas 24: 4.

4. Fontenelle ROS, Morais SM, Brito EHS, Kerntopf MR, Brilhante RSN, et al. (2007) Chemical composition, toxicological aspects and antifungal activity of essential oil from Lippia sidoides Cham. J Antimicrob Chemother 59(5): 934-940.

5. Botelho MA, Nogueira NA, Bastos GM, Fonseca SG, Lemos TL, et al. (2007) Antimicrobial activity of the essential oil from Lippia sidoides, carvacrol and thymol against oral pathogens Braz. J Med Biol Res 40(3): 349-356.

6. Alves PB, Evangelino TS, Blank AF, Santos RB, Freitas FP, et al. (2003) Antimicrobial activity of the essential oil from Lippia sidoides, carvacrol and thymol against oral pathogens Resumos da 30aㅡ Reunião Anual da Sociedade Brasileira de Química. Aguas de Lindóia-SP, Brasil.

7. Monteiro MV, de Melo Leite AK, Bertini LM, de Morais SM, NunesPinheiro DC (2007) Topical anti-inflammatory, gastroprotective and antioxidant effects of the essential oil of Lippia sidoides Cham. Leaves. J. Ethnopharmacol 111(2): 378.

8. Veras HN, Araruna MK, Costa JG, Coutinho HD, Kerntopf MR, et al (2013) Topical antiinflammatory activity of essential oil of Lippia sidoides Cham: possible mechanism of action. Phytother Res 27(2): 179-185

9. de Oliveira ML, Bezerra BM, Leite LO, Girão VC, Nunes-Pinheiro DC (2014) Topical continuous use of Lippia sidoides Cham. Essential oil induces cutaneous inflammatory response, but does not delay wound healing process. J Ethnopharmacol 153(1): 283-289. 
10. Siqueira-Moura MP, Primo FL, Espreafico EM, Tedesco AC (2013) Development, characterization, and photocytotoxicity assessment on human melanoma of chloroaluminum phthalocyanine nanocapsules. Mater Sci Eng C Mater Biol Appl 33(3): 1744.

11. Grillo R, MeloNFS, Araújo DR, de Paula E, Dias NI, et al. (2009) Validation of an HPLC method for quantitative determination of benzocaine in PHBV-microparticles and PLA-nanoparticles. Lat Am J Pharm 28(3): 393-399.

12. Carreño F, Paese K, Silva CDM, Guterres SS, Costa,TD (2015) Characterizing the mechanism of quetiapine distribution in lipidcore nanocapsules pseudo-phases using a validated lc/uv method. Quim. Nova 38(9): 1181.

13. Branquinho RT, Mosqueira VC, Kano EK, de Souza J, Dorim DD, et al. (2014) HPLC-DAD and UV-Spectrophotometry for the Determination of Lychnopholide in Nanocapsule Dosage Form: Validation and Application to Release Kinetic Study. J Chromatogr Sci 52(1): 19-26.

14. Leal LKAM, Oliveira VM, Araruna SM, Miranda MCC, Oliveira FMA, (2003) Análise de timol por CLAE na tintura de Lippia sidoides Cham.(alecrim-pimenta) produzida em diferentes estágios de desenvolvimento da planta. Rev Bras de Farmacogn 13: 9.

15. Taha KF, Hetta MH, Bakeer WI, Yassin NAZ, Ibrahim BMM, et al (2016) Comparative phytochemical and pharmacological study of antitussive and antimicrobial effects of boswellia and thyme essential oils. Pharma Chem 8(1): 67-83.

16. Roosta M, Ghaedi M, Daneshfar A, Sahraei R (2015) Ultrasound assisted microextraction-nano material solid phase dispersion for extraction and determination of thymol and carvacrol in pharmaceutical samples: Experimental design methodology J Chromatogr B Analyt Technol Biomed Life Sci 975: 34
17. Benelli L, Souza CRF, Oliveira WP (2013) Quality changes during spouted bed drying of Pepper-Rosmarin extract. The Canadian Journal of Chemical Engineering 91(11): 1837.

18. Fessi H, Puisieux F, Devissaguet JP, Ammoury N, Benita S (1989) Nanocapsule formation by interfacial polymer deposition following solvent displacement. Int J Pharm 55(1): R1-R4.

19. Brasil (2003) Resolução (RE) no 899, de 29 de maio de 2003. Diário Oficial [da] República Federativa do Brasil. Brasília, Brazil.

20. Ribeiro FAL, Ferreira MMC, Morano SC, Silva LR, Schneider RP (2008) Planilha de validação: uma nova ferramenta para estimar figuras de mérito na validação de métodos analíticos univariados. Quim Nova 31: 164.

21. Eloy JO, Oliveira ECV, Marotta-Oliveira SS, Saraiva J, Marchetti JM (2012) Desenvolvimento e validação de um método analítico por CLAE para quantificação de ácido ursólico em dispersões sólidas. Quim Nova 35(5): 1036-1040

22. Da Rosa HB, Tolotti RC, Miron, Diogo dos Santos, de Souza KCB (2012) Desenvolvimento e validação de método para o doseamento de tibolona em cápsulas por cromatografia líquida de alta eficiência. Quim Nova 35: 1030.

23. Brito NM, Junior OPDA, Polese L, Ribeiro ML (2003) Validação de métodos analíticos: estratégia e discussão. Pesticidas: Revista de Ecotoxicologia e Meio Ambiente 13: 129.

24. Lopes CC, Salgado HR (2009) Development of a validated stabilityindicating LC assay and stress degradation studies of linezolid in tablets. Chromatographia 69(2): 129-135. 